
\title{
28 Research Suare \\ Comparison of Sampling Methods for Small Oxbow wetland Fish Communities
}

Dylan M Osterhaus ( $\square$ dylano1@iastate.edu )

lowa State University https://orcid.org/0000-0002-9044-1090

Samuel S Leberg

lowa State University

Clay L Pierce

lowa State University

Timothy W Stewart

lowa State University

Audrey McCombs

lowa State University

\section{Research Article}

Keywords: Oxbow, endangered, restoration, monitoring, sampling, efficacy

Posted Date: July 13th, 2021

DOI: https://doi.org/10.21203/rs.3.rs-672132/v1

License: (c) (1) This work is licensed under a Creative Commons Attribution 4.0 International License.

Read Full License 
Comparison of Sampling Methods for Small Oxbow wetland Fish Communities Manuscript to be submitted to: Wetlands Dylan M. Osterhaus ${ }^{1,3}$, SAmuel S. Leberg $^{1}$, Clay L. PierCe ${ }^{1}$, Timothy W. STEWART ${ }^{1}$,
Audrey McCombs ${ }^{2}$
${ }^{1}$ Iowa State University Department of Natural Resources Ecology and Management, 2310 Pammel Drive, 339 Science II, Ames, IA 50011

${ }^{2}$ Iowa State University Department of Statistics, 2438 Osborn Drive, Ames, IA 50011

${ }_{3}^{3}$ Corresponding author: dylanol@iastate.edu ORCID: 0000-0002-9044-1090

\begin{abstract}
\end{abstract}
The value of wetland ecosystems is becoming increasingly recognized, promoting actions needed to preserve and restore them. Post-restoration monitoring is necessary to analyze restoration success or failure, thereby informing subsequent management decisions. Standardized monitoring protocols enable comparison of responses to restoration actions. Within the Midwestern United States, restoration of oxbow wetlands has become the focus of targeted restoration. Management objectives include recovery of biodiversity and sensitive species, and enhanced ecosystem services. The fish communities of oxbows have been the subject of many monitoring studies as endangered Topeka Shiner (Notropis topeka) use these habitats for spawning. However, an optimal method for monitoring Topeka Shiner and other fishes in oxbows has not been described, thereby limiting our capacity to effectively manage these ecosystems. With a primary objective of identifying a standardized protocol for sampling fish in oxbow wetlands, we compared efficacy of four sampling methodologies (backpack electrofishing, fyke netting, minnow trapping, and seining) for fish community data collection. Seining and fyke netting were determined to be the most effective methods for sampling oxbow fish communities. Although seining and fyke netting produced similar taxonomic diversity and 
25 abundance values, qualitative analysis revealed that seining caused greater habitat disturbance

26 and stress to fish. Therefore, consideration must be given to how species present within the

27 wetland could be impacted by sampling disturbance when choosing between seining and fyke

28 netting.

29 Keywords: Oxbow, endangered, restoration, monitoring, sampling, efficacy

\section{ACKNOWLEDGEMENTS}

31 We thank our field technicians, S. Grinstead and C. Wood, for the many hours spent in

32 the field collecting the data presented within this manuscript. We also thank the various

33 collaborating entities and individuals who have made this project possible, either through

34 funding or support of the research efforts. Collaborators for this project include C. McKinney, K.

35 Wilke, A. Kenney, J. Olson, D. Weissenfluh, Iowa Soybean Association, Syngenta Crop

36 Protection LLC, The Nature Conservancy, and the U.S. Fish and Wildlife Service. Finally, we

37 thank the many landowners whose support was vital for the success of this project.

\section{INTRODUCTION}

Throughout the world, increasing emphasis is being placed on restoration of degraded

40 aquatic habitats and their ecosystem services (Palmer et al. 2014). Wetlands are among the most

41 impacted aquatic ecosystems, with declines in both areal coverage and habitat quality occurring

42 as the global human population increases (Davidson 2014). Fortunately, recognition of the value

43 of wetlands has generated interest in preserving and restoring them. Wetland restoration

44 activities range in scope and complexity from watershed-scale undertakings to targeted fine-scale

45 enhancements of habitats. As these activities have expanded, so has realization of the value of

46 monitoring sites post-restoration to assess management successes or failures (Rubin et al. 2017;

47 Roni et al. 2018). Standardized monitoring protocols are imperative for comparing success of 
48 different restoration strategies and responses of different types of wetlands to these management

49 actions. (Roni et al. 2018).

Within the Midwestern United States, oxbow wetlands (hereafter oxbows) have recently

51 become the focus of targeted restoration efforts. Oxbows are floodplain habitats consisting of

52 river meanders that have been disconnected from the main channel through natural erosional

53 processes, creating an off-channel lentic habitat (Ward et al. 2002; Charlton 2008). As prairies,

54 forests, and other forms of natural land cover in the region were replaced by cropland and

55 pasture, streams were channelized, eliminating many oxbows (Dodds et al. 2004; Costigan and

56 Daniels 2012). As oxbows declined in number, their ecosystem services were also lost. In

57 floodplain habitats, oxbows are especially valuable because they retain water, thereby reducing

58 downstream flooding (Schilling 2017). By capturing and sequestering nutrients, oxbows can

59 contribute to improved stream water quality (Schilling 2017; Schilling 2018). Additionally,

60 oxbows contribute to increased biodiversity by providing essential wetland habitat for many

61 species (Miranda 2005; Rodrigues 2015; Jones et al. 2015; Schilling et al. 2018).

62 Within the states of Iowa, Minnesota, and South Dakota, restoration of oxbows has

63 increased substantially over the last twenty years. In Iowa alone, restoration of oxbows has

64 increased from 1.2 restorations per year from 2001-2005 to 12.8 restorations per year from 2016-

652020 (Fig. 1). Iowa oxbows are being restored because of ecosystem services described above,

66 and because they appear to provide critically important habitat for the Topeka Shiner Notropis

67 topeka, a species of fish that is listed by the United States Fish and Wildlife Service as an

68 endangered species (Tabor 1998; Schilling et al. 2017; Schilling et al. 2018; Simpson et al.

69 2019). 
Accelerating oxbow restoration has led to increased monitoring of these ecosystems by

71 The Nature Conservancy, the United States Fish and Wildlife Service, the United States

72 Geological Survey and other entities. Monitoring projects are conducted in part to determine

73 success or failure of restoring oxbow ecosystem services. Monitoring typically involves

74 collecting habitat data (depth, width, length, bank angles, substrate, canopy cover, etc.) and

75 conducting plant and invertebrate community surveys. Given that oxbows are critical habitat for

76 Topeka Shiner, research has also focused on fish communities of restored and unrestored oxbows

77 (Bakevich et al. 2013; Fischer et al. 2018; Simpson et al. 2019).

78 While many studies have examined oxbow fish communities, a standard sampling

79 protocol does not exist for these habitats, and some methods are likely more effective than others

80 (Bakevich et al. 2013). Sampling methodologies employed in previous fish community surveys

81 include seining with a bag seine of variable sizes and numbers of seine passes (Bakevich et al.

82 2013), blocking the oxbow into four sections and sampling three while leaving one section as an

83 undisturbed fish refuge (Fisher et al. 2018), and "scoop" seining (1.2 x $1.2 \mathrm{~m}$ seine with $6.4 \mathrm{~mm}$

84 mesh; Dahle 2001). Because the Topeka Shiner is a rarely encountered species with a restricted

85 geographic distribution and specific habitat requirements, it is important to identify the most

86 effective fish community survey method for oxbows. An ideal method would produce

87 consistently accurate population data while minimizing stress to fish. Development of a standard

88 protocol based on this sampling method will enable sampling without causing significant fish

89 mortality, and direct comparison of results from fish surveys conducted in different oxbows.

90 In this study, we quantitatively compared values for three fish community metrics (total

91 CPUE, species richness, and $10^{\text {th }}-90^{\text {th }}$ quantile length ranges of fish collected) that were obtained

92 using four sampling methods. Additionally, we qualitatively compared these methods in terms 
93 of ease of use, stress to fish, habitat disturbance, ability to sample in dense vegetation, and ability

94 to sample in deep water. Objectives were to identify best practices for describing fish community

95 structure in oxbows, and propose a standard protocol for conducting fish community surveys.

\section{METHODS}

97 Study sites consisted of 12 recently restored oxbows located in central Iowa (10 within

98 the Boone River basin, two within the North Raccoon River basin; Fig. 2). Oxbow length, width

99 and depth ranged from $23 \mathrm{~m}$ to $139 \mathrm{~m}, 4.8 \mathrm{~m}$ to $20.4 \mathrm{~m}$, and $0.56 \mathrm{~m}$ to $0.98 \mathrm{~m}$, respectively, with

100 average values of $77.4 \mathrm{~m}, 10.0 \mathrm{~m}$, and $0.69 \mathrm{~m}$ (Average \pm SD; Table 1). Fish communities at all

101 oxbows were surveyed over a four-week period using four sampling methodologies (backpack

102 electrofishing, fyke netting, minnow trapping, seining). Seining is a frequently-used fish

103 sampling methodology in oxbows (Simpson et al. 2019; Bakevich et al. 2013). Fyke netting and

104 minnow trapping are commonly used to sample fish in a variety of depressional wetlands (Bryant

105 2001; Kneib and Craig 2001; Ruetz et al. 2007; Maurer et al. 2014). Although infrequently used

106 in wetlands, we included backpack electrofishing given the widespread use of this sampling

107 method in fisheries field research.

108 Oxbow sampling sequence and order of methodology implementation were randomized

109 (using a random number generator) to control for time effects on results. For each sampling

110 method, all fish collected were identified to species and total numbers were counted. Total

111 lengths of the first 50 recovered individuals for each species were measured. All fishes were

112 subsequently released into the oxbow where they were captured.

\section{Sampling Methods}

114 Backpack electrofishing was performed by a single pass with a backpack unit (Smith-

115 Root LR-20B Backpack Electrofisher) across all wadeable habitat by walking along the entire

116 shoreline perimeter. One investigator carried the backpack, while one netter on each side 
117 collected fish. Electrofishing settings were determined based on conductivity of water in the

118 oxbow (10-500 $\mu \mathrm{s} / \mathrm{cm}, 200-300$ volts; 500-800 $\mu \mathrm{s} / \mathrm{cm}, 150-200$ volts; 800-1000 $\mu \mathrm{s} / \mathrm{cm}, 120-180$

119 volts; >1000 $\mu \mathrm{s} / \mathrm{cm}, 100-150$ volts).

120 Fyke netting consisted of placing three, un-baited, mini-fyke nets $(4.0 \mathrm{~m}$ lead, $0.6 \mathrm{~cm}$

121 mesh, largest hoop opening $=0.6 \mathrm{~m} \times 1.2 \mathrm{~m}$ ) in each oxbow. Nets were placed perpendicular to

122 the shoreline within the open water zone at points spaced evenly along the length of the oxbow.

123 Fyke nets were deployed for $24 \mathrm{~h}$, and then retrieved.

124 Minnow trapping consisted of placing four, un-baited, minnow traps ( $2.5 \mathrm{~cm}$ opening, 0.6

$125 \mathrm{~cm}$ mesh, $0.4 \mathrm{~m}$ long $\times 0.2 \mathrm{~m}$ diameter) at points evenly spaced along the length of the oxbow

126 and at variable depths ( $0.3 \mathrm{~m}$ to $1.1 \mathrm{~m}$ ) with two traps on each bank. Minnow traps were

127 retrieved after $24 \mathrm{~h}$ of deployment.

128 Seining was conducted using a single pass of a bag seine $(10.7 \mathrm{~m} \times 1.8 \mathrm{~m}, 0.6 \mathrm{~cm}$ mesh or

$12916.8 \mathrm{~m} \times 1.8 \mathrm{~m}, 0.6 \mathrm{~cm}$ mesh depending on oxbow width) along the entire length of the oxbow.

130 For oxbows $<16 \mathrm{~m}$ in average width, the $10.7 \mathrm{~m}$ wide seine was used. For oxbows $>16 \mathrm{~m}$ in

131 average width, the $16.8 \mathrm{~m}$ wide seine was used. Simpson et al. (2019) found that a single seine

132 pass (rather than multiple passes) was sufficient for surveying the fish community of an oxbow.

133 A single seine pass is more desirable compared to multiple seine passes given the reduced effort,

134 and decreased fish stress and mortality (Bakevich et al. 2013).

\section{Fish Community Metrics and Data Analysis}

To investigate effects of sampling method, we focused our quantitative analyses on three

137 fish community metrics. Total catch per unit effort (CPUE) was measured as the number of fish

138 collected per $100 \mathrm{~m}^{2}$ sampled during the sampling event as is consistent with other studies

139 analyzing oxbow fish communities (Bakevich et al. 2013; Simpson et al. 2019). Species richness 
140 was quantified as the number of species collected from one oxbow during one sampling event.

141 The $10-90^{\text {th }}$ quantile range for lengths was calculated for each sampling event and these values

142 were used for comparison. Values for species richness and total CPUE were log transformed

143 prior to analysis. Qualitative analyses focused on five metrics (ease of use, perceived stress to

144 fish, perceived stress to habitat, ability to sample in dense vegetation, ability to sample deep

145 water).

146 All analyses and figures were conducted and created using program $\mathrm{R}$ (version 3.6.3; R

147 Core Team 2020) and packages emmeans (Lenth 2020), ggridges (Wilke 2020), vegan

148 (Oksanen et al. 2019), ggplot2 (Wickham 2016), Ime4 (Bates et al. 2015), and plyr (Wickham

149 2011). Fixed effects linear regression models were fit for each quantitative metric of interest

150 (species richness, total CPUE, $10^{\text {th }}-90^{\text {th }}$ quantile length range) with sampling method, oxbow,

151 and week included as additive predictors. A type III ANOVA was used to test for effects of

152 sampling method on each fish community metric. The emmeans function was used to examine

153 contrasts between sampling methods for each metric with results averaged over the levels of

154 oxbow and week and $\mathrm{P}$ values adjusted using the Tukey method for comparing a family of four

155 estimates. The critical value for statistically significant differences was $\mathrm{P} \leq 0.05$.

\section{RESULTS}

In total, 48 sampling events occurred (12 oxbows x 4 sampling events at each oxbow),

158 resulting in collection of 32862 individual fish and 26 species (Table 2). Within the sampling

159 period, a fish-kill occurred at one oxbow, likely due to low dissolved oxygen levels as a result of

160 decaying organic matter. Therefore, data from that oxbow were not included in analysis,

161 resulting in 11 oxbows and 44 sampling events included in statistical analysis.

$162 \quad$ Fathead Minnow Pimephales promelas was collected from all oxbows and represented 73

$163 \%$ of the fish collected during sampling. Golden Shiner Notemigonus crysoleucas was the second 
164 most common fish sampled, representing nearly $9 \%$ of the total catch, although this species was

165 collected from only 5 of the 11 oxbows. Seven of the 26 species collected represented over $97 \%$

166 of the total fish collected (Table 2). Five species were collected from only one oxbow while two

167 species were collected at each oxbow (Table 2). Two Topeka Shiner were collected during

168 sampling.

169 Sampling method had a significant effect on total CPUE $(\mathrm{P}<0.001)$, species richness $(\mathrm{P}$

$170<0.001)$, and fish lengths $(\mathrm{P}<0.002$; Tables 3-6). Total CPUE was significantly greater for fyke

171 netting and seining than backpack electrofishing and minnow trapping (Table 4; $\mathrm{P}<0.0001$ ).

172 Species richness was significantly greater for fyke netting, seining and backpack electrofishing

173 than minnow trapping (Table 5; $\mathrm{P} \leq 0.009$ ). The range of fish lengths collected by seining and

174 fyke netting were significantly larger than the range of fish lengths collected by minnow trapping

175 (Table 6; $\mathrm{P}<0.002$ ). The range of fish lengths collected by backpack electrofishing was not

176 significantly different from the range collected by the other three methods.

177

\section{Backpack Electrofishing}

178 Total CPUE values obtained via backpack electrofishing were low compared to other

179 methods, indicating that this method is ineffective for sampling oxbow fish communities (Table

180 4). Species richness values produced by backpack electrofishing (range $=1-11$ species per

181 oxbow based on 11 sampling events) were lower than fyke netting (2-16 species) and seining

182 (2-16 species), indicating that backpack electrofishing fails to detect many species occupying

183 an oxbow (Table 3). Backpack electrofishing was successful in collecting the 13 most common

184 of the 26 total species collected (Table 2). However, seven of the 13 least common species were

185 absent from collections made via backpack electrofishing. Length frequency distribution data 
186 indicate that backpack electrofishing disproportionally sampled smaller fish than other methods

187 we employed (Fig. 3).

188

\section{Fyke Netting}

Total CPUE values from fyke netting were comparatively high, indicating that this

192 technique is effective in capturing fishes occupying the oxbow (Table 4). Furthermore, fyke

193 netting resulted in the collection of 24 of the 26 fish species recorded during the study, missing

194 only Rock Bass (representing the lowest proportion of total catch, collected at one oxbow) and

195 Yellow Perch (representing the fourth lowest proportion of total catch, collected at one oxbow)

196 (Table 2). Additionally, a single Topeka Shiner was collected via fyke netting at one oxbow.

197 These findings, in combination with the high species richness values, indicate that fyke netting is

198 effective at detecting rarer species. Length frequency distribution results from fyke netting

199 indicate that this method effectively samples the entire range of fish sizes present in the oxbow

200 compared to other methods used (Fig. 3).

Minnow Trapping

202 Total CPUE values from minnow trapping were the lowest of the four methods tested

203 (Table 4). Minnow trapping resulted in collection of seven species in total, but no more than

204 three species were collected during any one sampling event (Table 3). Lengths of fish collected

205 via minnow trapping were significantly greater than those collected via backpack electrofishing,

206 and fyke netting but were similar to those collected via seining (Table 5). Minnow trapping

207 appears to be more size-selective for fish in the length range of 40 to $90 \mathrm{~mm}$, in comparison to

208 other sampling methods (Fig. 3). 
Total CPUE values indicate that sampling efficiency via seining is high. Seining resulted

211 in collection of 24 of the 26 species found during this study, missing only Black Crappie (tenth

212 lowest proportion of total catch, collected at one oxbow) and Carmine Shiner (third lowest

213 proportion of total catch, collected at one oxbow; Table 2). The range of species richness values

214 generated by seining (2-16 species) was identical to that of fyke netting (Table 3). Furthermore, a

215 single Topeka Shiner was collected via seining at one oxbow. As was true for fyke netting, it

216 appears that seining effectively samples rarer species of fish. Seining does not appear to be size-

217 selective (Fig. 3).

\section{DISCUSSION}

\section{Comparison Of Sampling Methods For Fish Community Sampling}

Our findings indicate that seining and fyke netting are the most effective sampling

221 methodologies evaluated in this study. These conclusions are based on high total CPUE and

222 species richness values, unbiased sampling of various size classes, ability to sample deep-water

223 habitat, and ability to detect presence of Topeka Shiner. These two methods performed more

224 effectively in comparison to backpack electrofishing and minnow trapping. While fyke netting

225 and seining both appear to effectively sample oxbow fish communities, there are differences in

226 ease of implementation of each gear type as well as the level of habitat disturbance generated.

\section{Backpack Electrofishing}

228 Backpack electrofishing was a difficult technique to use in oxbows. First and foremost,

229 turbidity is typically high within oxbows and sediment is easily suspended. Given that efficacy

230 of backpack electrofishing relies heavily on the netter's ability to see stunned fish (Zalewski and

231 Cowx 1990), relying on this sampling method in turbid systems is not recommended.

232 Furthermore, the sampled oxbows frequently contained areas in which water depth was $>1 \mathrm{~m}$. To 
233 maintain the backpack electrofishing unit's functionality by avoiding the submersion of the

234 circuitry and power source, much deep-water habitat was unsampled. Presence of dense

235 submerged plants also created difficulty because fish stunned by the electrical currents became

236 ensnared in vegetation and did not surface.

237 Backpack electrofishing can also be stressful to fish (Snyder 2003; Awata et al. 2013).

238 Handling stress may be high as this method does not lend itself well to holding fish for data

239 collection after sampling. Fish are transferred from the collection net to a larger holding

240 container within the oxbow, which at times involves a significant amount of handling. In terms

241 of stress to the habitat, backpack electrofishing in our study involved three individuals walking

242 through the entire wadeable portion of the oxbow. This leads to heavy disturbance of sediment,

243 increased turbidity, and displacement of vegetation.

\section{Fyke Netting}

245 Fyke netting had multiple drawbacks (amount and weight of gear, time requirements) and 246 benefits (low stress to fish, ability to sample in deeper water and dense vegetation). The amount

247 and weight of gear needed for fyke netting created difficulty when hauling gear to study sites (in

248 our case, a distance up to $1 \mathrm{~km}$ ). Fyke netting is time-consuming as nets must be deployed for 24

249 h, which necessitates site visits on successive days. However, fyke nets are effective at sampling

250 fish communities in densely vegetated habitats (Maurer et al., 2014). Furthermore, habitat

251 disruption by fyke netting is not as extensive as that caused by more active forms of sampling,

252 including backpack electrofishing and seining. For fyke netting, habitat disruption within an

253 oxbow is generally confined to placement locations of fyke nets, and does not result in

254 widespread disturbance of vegetation and benthic substrate. 
Handling stress from fyke netting is likely similar to that caused by minnow trapping but

256 lower than seining and backpack electrofishing. In fyke netting, fish can be quickly transferred

257 from the net to a holding container and then counted and released immediately. However, fish

258 are restrained within the net for up to $24 \mathrm{~h}$, depending on when they enter the net. This restraint

259 may disrupt normal behavioral patterns and expose fish to increased predation risk if the net is

260 occupied by piscivores such as Green Sunfish, Largemouth Bass, or turtles.

\section{Minnow Trapping}

Minnow trapping is easy to implement as a sampling practice given the small size and

263 low cost of traps and the ease with which they can be placed into the oxbow. However, minnow

264 trapping is likely an ineffective sampling methodology for oxbows with significant aquatic

265 vegetation. Aquatic macrophytes along the bottoms of an oxbow may inhibit effectiveness of

266 minnow traps because entry funnels may become clogged or covered with vegetation. Also,

267 given the small size of the funnel leading to the trap entrance, it is likely that each trap is

268 sampling only a small proportion of the total habitat present at an oxbow in comparison to

269 backpack electrofishing, fyke netting, and seining.

270 Minnow trapping causes minimal disturbance to oxbow habitat. Minnow traps can be

271 deployed from the shoreline, without an investigator having to enter aquatic habitat. While

272 habitat disturbance may be limited, stress to fish collected via minnow trapping may occur.

273 Similar to fyke netting, fish confined within a minnow trap may experience disruption to normal

274 behavioral processes, such as feeding, for up to $24 \mathrm{~h}$. However, unlike fyke netting, given the

275 size selectiveness of minnow trapping, fish in traps are unlikely to experience increased

276 predation risk because larger piscivores are unable to enter traps. 
279 investigators pulling the seine may remain along the shallow shoreline of the oxbow during

280 sampling. Fisher et al. (2018) documented detection probabilities ranging from $40 \%$ to over $90 \%$

281 for fish species in similar oxbows using similar seining techniques. However, for oxbows with

282 dense aquatic vegetation or an abundance of woody debris/boulders, seining becomes arduous

283 given the active nature of this method. For seining, fish are held entirely in the water until the

284 moment each individual is counted, which may reduce handling stress. Also, the amount of time

285 in which an individual fish is impacted is minimal compared to passive forms of sampling which

286 may result in a fish being trapped for $24 \mathrm{~h}$. However, when oxbows with significant aquatic

287 vegetation are sampled, a risk exists for entanglement of fish within aquatic vegetation collected

288 by the seine. Furthermore, seining can lead to habitat destruction within the oxbow. The lead line

289 of a seine may disturb an oxbow's floor and up-root aquatic vegetation. If sampling occurs

290 during the breeding season for nest building centrarchid sunfishes such as the Green Sunfish, and

291 Bluegill (Topeka Shiner nest in association with each of these species; Pflieger 1997; Dahle

292 2001; Stark 2002; Witte 2009), this reproductive activity could be compromised.

293 Seining is one of the most common methods employed to sample fish in shallow-water

294 habitats. It is the simplest method to employ in terms of gear needed. Furthermore, given the

295 characteristic U-shaped depth profiles and narrow wetted widths of oxbows, a seine can be

296 pulled through the entirety of the habitat, barring any large obstructions (submerged woody

297 debris, boulders etc.). Also, seining allows for minimal handling because can be held in the water 298 during processing and data collection. 
Minnow trapping is ineffective in accurately describing the oxbow fish community. Other

301 investigators determined that the catch of minnow traps is biased towards common species and is

302 size-selective; our findings corroborate these studies (Layman and Smith 2001; Lapointe et al.

303 2006). Given the inability to effectively and unbiasedly sample the fish community, we do not

304 recommend use of minnow trapping as a sampling method for oxbow fish communities.

305 Furthermore, given the low CPUE values, ineffectiveness in sampling rarer species, difficulties

306 in sampling deep and vegetated water, and high stress to habitat and fish, we do not recommend

307 backpack electrofishing as a sampling methodology for oxbow fish communities. However, we

308 do recommend both seining and fyke netting as best practices for oxbow fish community

309 sampling. Quantitively, fyke netting and seining appear to be comparable in fish community

310 sampling efficacy. In our study, we found differences in lengths of fish collected, however, both

311 sampling method appears to sample sizes classes without bias (Fig. 3).

312 When choosing between fyke netting and seining, consideration must be given to the

313 amount of time needed to conduct sampling, habitat disturbance, habitat characteristics,

314 accessibility of the oxbow, and time of year. For oxbows containing large quantities of aquatic

315 vegetation or woody debris or boulders, fyke netting is the preferred sampling method. However,

316 given the weight and difficulty in transporting fyke nets from a vehicle to the oxbow, seining

317 may be preferable for oxbows that are not readily accessible by vehicle.

318 Recent Topeka Shiner surveys have involved sampling many oxbows over a short time

319 period (Bakevich et al. 2013; Simpson et al. 2019). For studies constrained by a short timeline,

320 seining may be more desirable as an oxbow can be visited once and sampled via seine within a

321 few hours, while fyke netting requires two days and two visits to the oxbow to complete.

322 However, if sampling is to occur during the breeding season of Topeka Shiner (or other species 
323 of conservation concern depending upon the location of the study area), fyke netting is less likely

324 to disturb habitat and may be preferable to seining.

\section{Special Considerations for Topeka Shiner Sampling}

Considering Topeka Shiner's imperiled status, it is crucial that a sampling method is

327 employed that has a high likelihood of detecting this species when it is present. Although only

328 two specimens were collected in our study, it appears that fyke netting and seining were the best

329 methods to determine presence or absence of Topeka Shiner within an oxbow. In addition to

330 sampling method effectiveness, consideration must be given to stress experienced by fish as

331 surveys are conducted. These considerations are especially significant when handling species of

332 greatest conservation concern. We recommend that during the breeding season for Topeka

333 Shiner (mid-May to early August; Dahle, 2001; Witte, 2009), fyke nets or other passive sampling

334 methods which are comparatively unlikely to disrupt spawning habitat should be used to

335 minimize disturbance of reproduction. Outside of the potential breeding season, active sampling

336 methods such as seining can be used to sample habitats where Topeka Shiner may be present.

337 Fischer et al. (2018) documented detection probability of over 90\% for Topeka Shiner in similar

338 oxbows using similar seining techniques.

339 In summary, the monitoring of oxbows, both before and after restoration, is necessary to

340 understand impacts of restoration on the fish community present within the oxbow. We must

341 understand how restoration impacts the fish community to improve management practices that

342 maximize benefits for target species (in this case, Topeka Shiner). We recommend that during

343 the breeding season for Topeka Shiner (mid-May to early August), fyke netting should be used

344 as the primary sampling methodology for oxbows that may hold the species. Outside of the 
345 breeding season for Topeka Shiner, we recommend either seining or fyke netting as the primary

346 sampling methodology depending upon physical characteristics of the oxbow being sampled. 


\section{DECLARATIONS}

$349 \quad$ Funding

350 Funding for this study was provided by Syngenta Crop Protection LLC and the Iowa Soybean

351 Association.

352 Conflicts of interest/Competing interests

353 The authors declare no conflicts of or competing interests.

354 Availability of data and material

355 The datasets used and/or analyzed during the current study are available from the corresponding

356 author on reasonable request.

357 Code availability

358 The code used during the current study is available from the corresponding author on reasonable 359 request.

360 Authors' Contributions

361 SS participated in the design and implementation of field data collection for this study. CL

362 acquired the funding necessary to complete this study and provided edits and comments on

363 manuscript drafts. TW provided guidance on study design as well as manuscript editing. AM

364 provided guidance for statistical analysis. DO participated in the design and implementation of

365 field data collection, analysis of data, and was the primary author of the manuscript. All authors

366 read and approved the manuscript.

367 Ethics Approval

368 This study was approved by the Iowa State University Office of Research Ethics Institutional

369 Animal Care and Use Committee

370 Consent to Participate 
371 Not applicable

372

373 Consent for Publication

374 Not applicable 


\section{LITERATURE CITED}

376 AWATA S., T. TSURUTA, T. YADA, AND K. IGUCHI. 2013. Stress hormone response in ayu Plecoglossus altivelis in reaction to different catching methods: comparison between electrofishing and cast netting. Fish. Sci., 79:157-162.

BAKEVICH, B. D., C. L. PIERCE, AND M. C. QUIST. 2013. Habitat, fish species, and fish assemblage associations of the topeka shiner in west-central Iowa. N. Am. J. Fish. Manag., 33:1258-1268.

BRYANT, M. D. 2000. Estimating fish populations by removal methods with minnow traps in southeast Alaska streams. N. Am. J. Fish. Manag., 20:923-930.

DAVIDSON, N. C. 2014. How much wetland has the world lost? Long-term and recent trends in

CHARLTON, R. 2008. Fundamentals of fluvial geomorphology. Routledge, New York.

COSTIGAN, K. H., AND M. D. DANIELS. 2012. Damming the prairie: human alteration of Great Plains river regimes. J. Hydrol., 444:90-99.

DAHLE, S. P. 2001. Studies of Topeka Shiner (Notropis topeka) life history and distribution in Minnesota. Master's thesis. University of Minnesota, Minneapolis, Minnesota.

DODDS, W. K., K. GIDO, M. R. WHILES, K. M. FRITZ, AND W. J. MATTHEWS. 2004. Life on the edge: the ecology of Great Plains prairie streams. BioSci., 54:205-2016.

FISCHER, J. R., B. D. BAKEVICH, C. P. SHEA, C. L. PIERCE, AND M. C. QUIST. 2018. 
KNEIB, R. T., AND A. H. CRAIG. 2001. Efficacy of minnow traps for sampling mummichogs in tidal marshes. Estuaries, 24:884-893.

LAPOINTE, N. W., L. D. CORKUM, AND N. E. MANDRAK. 2006. A comparison of methods for sampling fish diversity in shallow offshore waters of large rivers. N. Am. J. Fish. Manag., 26:503-513.

LAYMAN, C. A., AND D. E. SMITH. 2001. Sampling bias of minnow traps in shallow aquatic habitats on the eastern shore of Virginia. Wetl. Sci., 21:145-154.

MAURER, K. M., T. W. STEWART, AND F. O. LORENZ. 2014. Direct and indirect effects of fish on invertebrates and Tiger Salamanders in prairie pothole wetlands. Wetlands, $34: 735-745$.

MIRANDA, L. E. 2005. Fish assemblages in oxbow lakes relative to connectivity with the Mississippi River. T. Am. Fish. Soc., 134:1480-1489.

PALMER, M. A., K. L. HONDULA, AND B. J. KOCH. 2014. Ecological restoration of streams and river: shifting strategies and shifting goals. Annu. Rev. Ecol. Syst., 45:247-269.

PFLIEGER, W. F. 1997. The fishes of Missouri, 2nd edition. Missouri Department of Conservation Jefferson City, Missouri.

R CORE TEAM. 2020. R: A language and environment for statistical computing. R Foundation for Statistical Computing, Vienna, Austria.

RODRIGUES, J. M. G. 2015. Cultural services in aquatic ecosystems. Ecosystem Services and River Basin Ecohydrology, Springer, Dordrecht.

RONI, P., U. ABERG, AND C. WEBER. 2018. A review of approaches for monitoring the effectiveness of regional river habitat restoration programs. N. Am. J. Fish. Manag., 38:1170-1186. 
422 RUETZ, C. R., D. G. UZARSKI, D. M. KRUEGER, AND E. S. RUTHERFORD. 2007.

423 Sampling a littoral fish assemblage: comparison of small-mesh fyke netting and boat

424 electrofishing. N. Am. J. Fish. Manag., 27:825-831.

425 SCHILLING, K. E., K. KULT, A. SEEMON, K. WILKE, AND C. S. JONES. 2018. Nitrate-N

426 load reduction measured in a central Iowa restored oxbow. Ecol. Eng., 124:19-22.

427 SCHILlinG, K. E., K. KULT, K. WILKE, M. STREETER, AND J. VOGELGESANG. 2017.

428 Nitrate reduction in a reconstructed floodplain oxbow fed by tile drainage. Ecol. Eng.,

$429 \quad 102: 98-107$.

430 SIMPSON, T. N., A. P. BYBEL, M. J. WEBER, C. L. PIERCE, AND K. J. ROE. 2019.

Occurrence, abundance, and associations of Topeka Shiners (Notropis topeka) in restored and unrestored oxbows in Iowa and Minnesota, USA. Aquat. Conserv.: Mar. Freshw. Ecosyst., 29:1735-1748.

SNYDER, D. E. 2003. Invited overview: conclusions from a review of electrofishing and its harmful effects on fish. Rev. Fish. Biol. Fisher., 13:445-453.

STARK, W. J., J. S. LUGINBILL, AND M. E. EBERLE. 2002. Natural history of a relict population of Topeka Shiner (Notropis topeka) in northwestern Kansas. Trans. Kans. Acad. Sci., 105:143-152.

TABOR, V. M. 1998. Final rule to list the Topeka Shiner as endangered. Federal Register diversity. Freshw. Biol., 47:517-539. 
444 WITTE, C. C., M. L. WILDHABER, A. ARAB, AND D. B. NOLTIE. 2009. Substrate choice of 445 territorial male Topeka shiners (Notropis topeka) in the absence of sunfish (Lepomis sp.). $446 \quad$ Ecol. Freshw. Fish., 18:350-359.

447 ZALEWSKI, M., AND I. G. COWX. 1990. Factors affecting the efficiency of electric fishing. $448 \quad$ Fishing with electricity. Fishing News Books Ltd., Blackwell Scientific Publications 89449 11. 


\section{TABLES AND FIGURES}

TABLE 1. Oxbow morphology for (A) 128 oxbows from Iowa and Minnesota and (B) the 12 oxbows sampled during the sampling methods efficacy project.

\begin{tabular}{|c|c|c|c|c|c|c|c|c|c|}
\hline \multirow{2}{*}{ Oxbows } & \multicolumn{3}{|l|}{ Length (m) } & \multicolumn{3}{|l|}{ Width (m) } & \multicolumn{3}{|l|}{ Depth (m) } \\
\hline & Average $( \pm \mathrm{SD})$ & Minimum & Maximum & Average $( \pm \mathrm{SD})$ & Minimum & Maximum & Average ( \pm SD) & Minimum & Maximum \\
\hline A & $107.6 \pm 83.4$ & 21 & 430 & $12.4 \pm 5.6$ & 3.1 & 35.1 & $0.54 \pm 0.29$ & 0.11 & 1.41 \\
\hline B & $77.4 \pm 39.8$ & 23 & 139 & $10.0 \pm 4.9$ & 4.8 & 20.4 & $0.69 \pm 0.13$ & 0.56 & 0.98 \\
\hline
\end{tabular}


TABLE 2. Abundance values for fish species captured in this study, including number of individuals in total and by sampling method, and its overall relative abundance (percent of total individuals). Values are based on 11 sampling events for each gear type in each wetland (18 May -11 June).

\begin{tabular}{|c|c|c|c|c|c|c|}
\hline \multirow[b]{2}{*}{ Species } & \multirow{2}{*}{$\begin{array}{c}\text { Total } \\
\text { individuals }\end{array}$} & \multirow{2}{*}{$\begin{array}{l}\text { Percent } \\
\text { of total }\end{array}$} & \multicolumn{4}{|c|}{ Numbers collected by sampling method } \\
\hline & & & $\begin{array}{c}\text { Backpack } \\
\text { electrofishing }\end{array}$ & $\begin{array}{c}\text { Fyke } \\
\text { netting }\end{array}$ & $\begin{array}{l}\text { Minnow } \\
\text { trapping }\end{array}$ & Seining \\
\hline $\begin{array}{l}\text { Fathead Minnow } \\
\text { Pimephales promelas }\end{array}$ & 23877 & 72.66 & 554 & 5471 & 849 & 17003 \\
\hline $\begin{array}{l}\text { Golden Shiner } \\
\text { Notemigonus crysoleucas }\end{array}$ & 2948 & 8.97 & 4 & 100 & 0 & 2844 \\
\hline $\begin{array}{l}\text { Black Bullhead } \\
\text { Ameiurus melas }\end{array}$ & 1194 & 3.63 & 22 & 202 & 2 & 968 \\
\hline $\begin{array}{l}\text { Brook Stickleback } \\
\text { Culaea inconstans }\end{array}$ & 1164 & 3.54 & 50 & 1083 & 4 & 27 \\
\hline $\begin{array}{l}\text { Green Sunfish } \\
\text { Lepomis cyanellus }\end{array}$ & 1113 & 3.39 & 101 & 521 & 23 & 468 \\
\hline $\begin{array}{l}\text { Common Shiner } \\
\text { Luxilus cornutus }\end{array}$ & 844 & 2.57 & 1 & 112 & 0 & 731 \\
\hline $\begin{array}{l}\text { Brassy Minnow } \\
\text { Hybognathus hankinsoni }\end{array}$ & 816 & 2.48 & 5 & 202 & 2 & 607 \\
\hline $\begin{array}{l}\text { Creek Chub } \\
\text { Semotilus atromaculatus }\end{array}$ & 262 & 0.80 & 11 & 88 & 9 & 154 \\
\hline $\begin{array}{l}\text { Bluegill } \\
\text { Lepomis macrochirus }\end{array}$ & 222 & 0.68 & 32 & 33 & 0 & 157 \\
\hline $\begin{array}{l}\text { Orangespotted Sunfish } \\
\text { Lepomis humilus }\end{array}$ & 106 & 0.32 & 7 & 6 & 0 & 93 \\
\hline $\begin{array}{l}\text { White Sucker } \\
\text { Catostomus commersonii }\end{array}$ & 94 & 0.29 & 5 & 11 & 0 & 78 \\
\hline $\begin{array}{l}\text { Bluntnose Minnow } \\
\text { Pimephales notatus }\end{array}$ & 58 & 0.18 & 1 & 52 & 0 & 5 \\
\hline $\begin{array}{l}\text { Sand Shiner } \\
\text { Notropis stramineus }\end{array}$ & 39 & 0.12 & 1 & 37 & 0 & 1 \\
\hline $\begin{array}{l}\text { Spotfin Shiner } \\
\text { Cyprinella spiloptera }\end{array}$ & 35 & 0.11 & 0 & 4 & 0 & 31 \\
\hline $\begin{array}{l}\text { Largemouth Bass } \\
\text { Micropterus salmoides }\end{array}$ & 23 & 0.07 & 4 & 1 & 0 & 18 \\
\hline $\begin{array}{l}\text { Black Crappie } \\
\text { Pomoxis nigromaculatus }\end{array}$ & 17 & 0.05 & 0 & 17 & 0 & 0 \\
\hline $\begin{array}{l}\text { Hornyhead Chub } \\
\text { Nocomis biguttatus }\end{array}$ & 10 & 0.03 & 1 & 6 & 0 & 3 \\
\hline
\end{tabular}


Table 2 Continued

\begin{tabular}{|c|c|c|c|c|c|c|}
\hline \multirow[b]{2}{*}{ Species } & \multirow{2}{*}{$\begin{array}{c}\text { Total } \\
\text { individuals }\end{array}$} & \multirow[b]{2}{*}{$\begin{array}{l}\text { Percent } \\
\text { of total }\end{array}$} & \multicolumn{4}{|c|}{ Numbers collected by sampling method } \\
\hline & & & $\begin{array}{c}\text { Backpack } \\
\text { electrofishing }\end{array}$ & $\begin{array}{l}\text { Fyke } \\
\text { netting }\end{array}$ & $\begin{array}{l}\text { Minnow } \\
\text { trapping }\end{array}$ & Seining \\
\hline $\begin{array}{l}\text { Western Blacknose Dace } \\
\text { Rhinichthys obtusus }\end{array}$ & 8 & 0.02 & 0 & 1 & 0 & 7 \\
\hline $\begin{array}{l}\text { Bigmouth Shiner } \\
\text { Notropis dorsalis }\end{array}$ & 7 & 0.02 & 0 & 6 & 0 & 1 \\
\hline $\begin{array}{l}\text { Central Stoneroller } \\
\text { Campostoma anomalum }\end{array}$ & 6 & 0.02 & 1 & 3 & 0 & 2 \\
\hline $\begin{array}{l}\text { Common Carp } \\
\text { Cyprinus carpio }\end{array}$ & 5 & 0.02 & 2 & 2 & 0 & 1 \\
\hline $\begin{array}{l}\text { Johnny Darter } \\
\text { Etheostoma nigrum }\end{array}$ & 5 & 0.02 & 1 & 1 & 2 & 1 \\
\hline $\begin{array}{l}\text { Yellow Perch } \\
\text { Perca flavescens }\end{array}$ & 3 & 0.01 & 2 & 0 & 0 & 1 \\
\hline $\begin{array}{l}\text { Carmine Shiner } \\
\text { Notropis percobromus }\end{array}$ & 3 & 0.01 & 0 & 3 & 0 & 0 \\
\hline $\begin{array}{l}\text { Topeka Shiner } \\
\text { Notropis topeka }\end{array}$ & 2 & 0.01 & 0 & 1 & 0 & 1 \\
\hline $\begin{array}{l}\text { Rock Bass } \\
\text { Ambloplites rupestris }\end{array}$ & 1 & 0.00 & 0 & 0 & 0 & 1 \\
\hline
\end{tabular}


TABLE 3. Descriptive statistics by sampling method for each quantitative metric. Overall mean $( \pm \mathrm{SD})$ and range values are based on 44 samples (11 wetlands $\mathrm{x} 4$ sampling events per wetland).

\begin{tabular}{|c|c|c|c|}
\hline $\begin{array}{l}\text { Sampling } \\
\text { Method }\end{array}$ & Species Richness & $\begin{array}{l}\text { Total CPUE (no. } \\
\text { fish per } 100 \mathrm{~m}^{2} \text { ) }\end{array}$ & $\begin{array}{l}\text { Fish length } \\
(\mathrm{mm})\end{array}$ \\
\hline \multicolumn{4}{|c|}{ Backpack Electrofishing } \\
\hline mean $\pm \mathrm{SD}$ & $4.18 \pm 3.03$ & $22.79 \pm 35.79$ & $59.93 \pm 34.81$ \\
\hline Range & $1-11$ & $0.62-113.82$ & $12-282$ \\
\hline \multicolumn{4}{|c|}{ Fyke Netting } \\
\hline mean $\pm \mathrm{SD}$ & $6.55 \pm 4.23$ & $293.65 \pm 469.51$ & $75.65 \pm 37.51$ \\
\hline Range & $2-16$ & $7.64-1383.28$ & $21-375$ \\
\hline \multicolumn{4}{|c|}{ Minnow Trapping } \\
\hline mean $\pm \mathrm{SD}$ & $1.45 \pm 0.82$ & $47.15 \pm 99.90$ & $60.86 \pm 13.87$ \\
\hline Range & $0-3$ & $0-276.92$ & $25-118$ \\
\hline \multicolumn{4}{|l|}{ Seining } \\
\hline mean $\pm \mathrm{SD}$ & $7.36 \pm 4.82$ & $449.37 \pm 630.99$ & $81.88 \pm 40.75$ \\
\hline Range & $2-16$ & $11.77-2114.04$ & $15-360$ \\
\hline
\end{tabular}


TABLE 4. Pairwise contrast statistics for each sampling method (Total CPUE; catch per unit effort). $\mathrm{P}$ values are based on Tukey's adjustment for multiple comparisons. When a significant difference occurred $(\mathrm{P} \leq 0.05)$, the sampling method with the higher Total CPUE is indicated in bold text.

\begin{tabular}{lllll}
\hline Contrast & Estimate & SE & Df & P \\
\hline Fyke Netting - Seining & -0.570 & 0.485 & 27 & 0.65 \\
Fyke Netting - Backpack Electrofishing & 2.580 & 0.451 & 27 & $<0.0001$ \\
Fyke Netting - Minnow Trapping & 3.198 & 0.462 & 27 & $<0.0001$ \\
Seining - Backpack Electrofishing & 3.150 & 0.485 & 27 & $<0.0001$ \\
Seining - Minnow Trapping & 3.768 & 0.491 & 27 & $<0.0001$ \\
Backpack Electrofishing - Minnow Trapping & 0.618 & 0.479 & 27 & 0.58 \\
\hline
\end{tabular}


TABLE 5. Pairwise contrast statistics for each sampling method (Species Richness). P values are based on Tukey's adjustment for multiple comparisons. When a significant difference occurred $(\mathrm{P} \leq 0.05)$, the sampling method with the higher Species Richness is indicated in bold text.

\begin{tabular}{lllll}
\hline Contrast & Estimate & SE & Df & P \\
\hline Fyke Netting - Seining & -0.143 & 0.249 & 27 & 0.94 \\
Fyke Netting - Backpack Electrofishing & 0.533 & 0.232 & 27 & 0.12 \\
Fyke Netting - Minnow Trapping & 1.382 & 0.237 & 27 & $<0.0001$ \\
Seining - Backpack Electrofishing & 0.676 & 0.249 & 27 & 0.05 \\
Seining - Minnow Trapping & 1.524 & 0.252 & 27 & $<0.0001$ \\
Backpack Electrofishing - Minnow Trapping & 0.849 & 0.246 & 27 & 0.0094 \\
\hline
\end{tabular}


TABLE 6. Pairwise contrast statistics for each sampling method $\left(10^{\text {th }}-90^{\text {th }}\right.$ quantile length ranges). P values are based on Tukey's adjustment for multiple comparisons. When a significant difference occurred $(\mathrm{P} \leq 0.05)$, the sampling method with the higher average $10^{\text {th }}-90^{\text {th }}$ quantile length range is indicated in bold text.

\begin{tabular}{lllll}
\hline Contrast & Estimate & SE & Df & P \\
\hline Fyke Netting - Seining & -12.0 & 12.8 & 27 & 0.7830 \\
Fyke Netting - Backpack Electrofishing & 21.0 & 12.1 & 27 & 0.3259 \\
Fyke Netting - Minnow Trapping & 40.8 & 12.4 & 27 & 0.0141 \\
Seining - Backpack Electrofishing & 33.0 & 12.4 & 27 & 0.0598 \\
Seining - Minnow Trapping & 52.9 & 13.3 & 27 & 0.0025 \\
Backpack Electrofishing - Minnow Trapping & 19.9 & 12.6 & 27 & 0.4060 \\
\hline
\end{tabular}




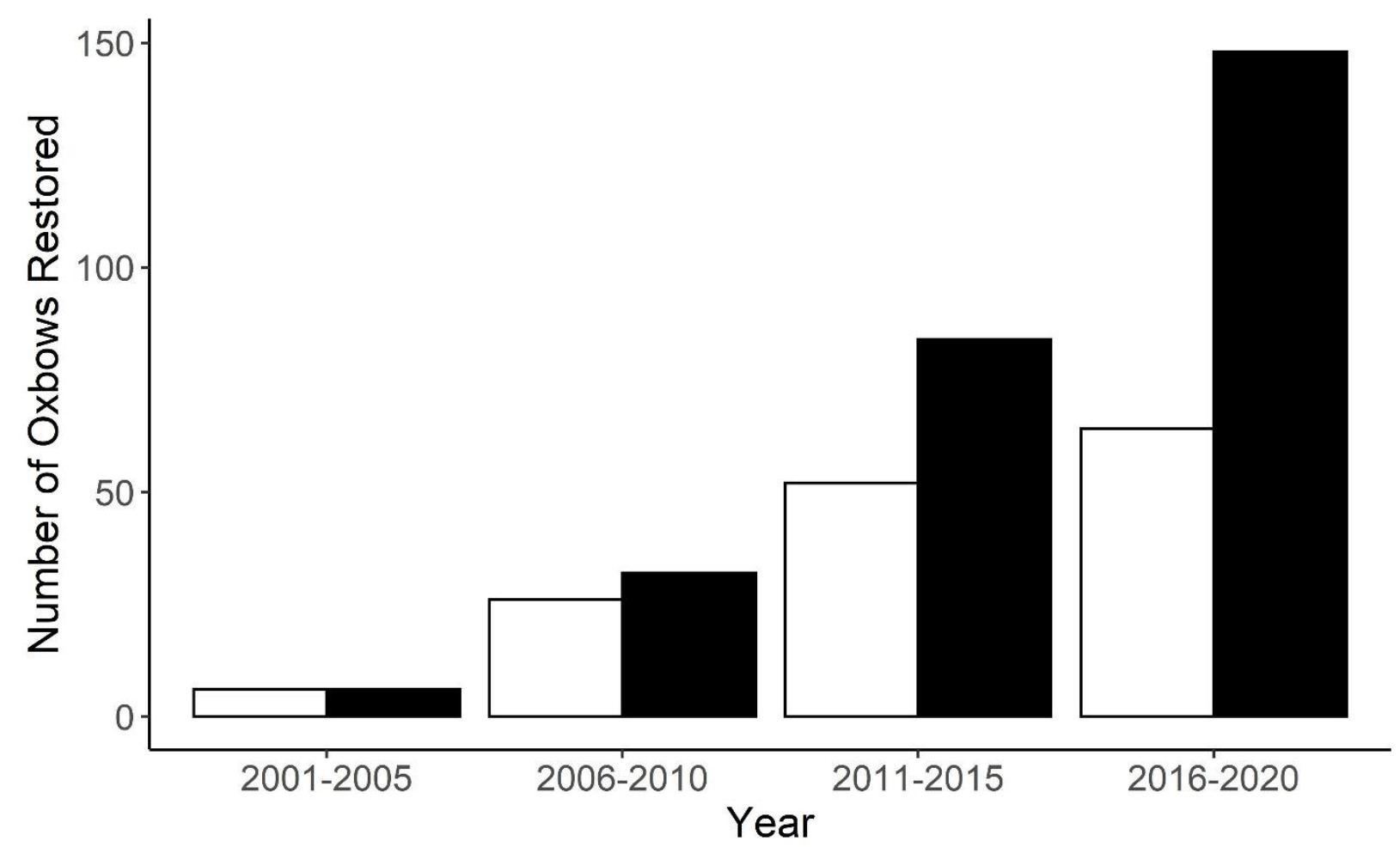

Fig. 1 Number of oxbows restored within Iowa, USA, per five-year period, 2001-2020.

Unshaded white bars represent oxbows restored during each five-year interval, and unshaded dark bars represent cumulative total. 


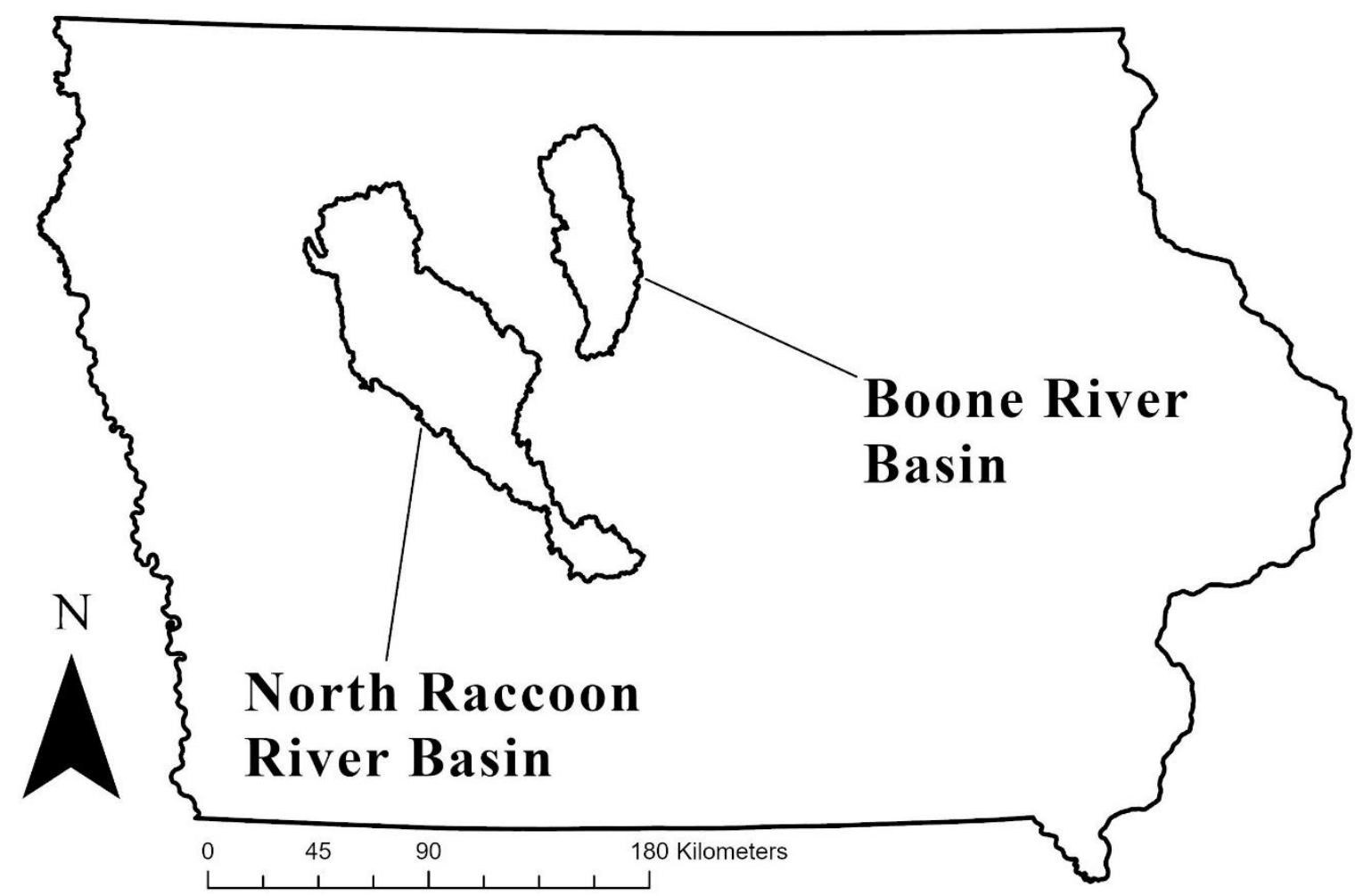

Fig. 2 Map of the HUC8 basins in Iowa, USA, in which the study occurred. 


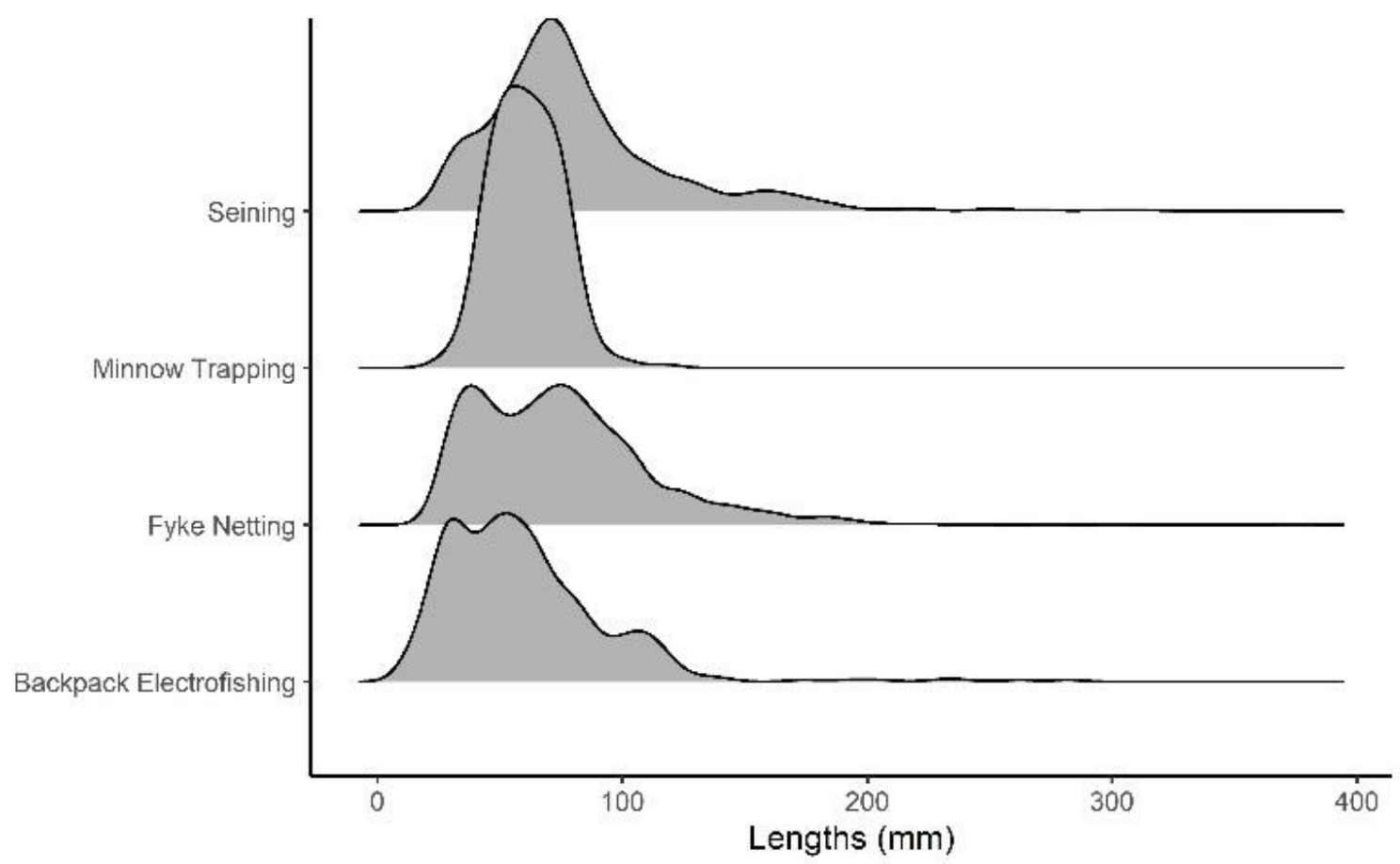

Fig. 3 Length frequency distribution for lengths as sampled by each sampling method. Height of the shaded region for each sampling method along y-axis represents the frequency of fishes of that length. 